\title{
In focus in HCB: from cell biology to tissue structure and function
}

\author{
Esther $\operatorname{Asan}^{1}$ (D)
}

Accepted: 14 October 2016 / Published online: 31 October 2016

(C) Springer-Verlag Berlin Heidelberg 2016

In the first Issue of Histochemistry in 1992, Springer announced a change in the leadership of the Journal, welcoming two new "managing editors," Detlev Drenckhahn of Würzburg (Fig. 1) and Jürgen Roth of Zürich. During the following more than two decades, this Editor-in-Chief team successfully steered the Journal through significant developments and changes resulting in its high quality and reputation in the scientific community. At the end of 2015, Detlev Drenckhahn stepped down from his position and a new leadership structure was announced with Jürgen Roth as Senior Editor-in-Chief and Takehiko Koji, Michael Schrader and Douglas Taatjes as Editors-in-Chief for authors from "AsiaPacific," "Greater Europe" and "The Americas," respectively (Roth 2016). This Special Issue of Histochemistry and Cell Biology presents Reviews and Original Articles with which members of the Editorial Board and former coworkers would like to express their sincere appreciation of Detlev Drenckhahn's contribution to the superior quality of Histochemistry and Cell Biology during his time as Co-Editor-in-Chief.

Shortly before taking up this position, Detlev Drenckhahn had moved his group from Marburg to Würzburg, where I became member of his team, and had started working on a thoroughly revised edition of the "Benninghoff", later the "Benninghoff-Drenckhahn", the standard textbook of Anatomy. The combination of work on the textbook and for the Journal provided an ideal reciprocal influence, inciting many stimulating discussions with colleagues on "hot" scientific topics, or on how to implement novel methodological developments in research projects, an exchange from which I profited for my own efforts as scientist, teacher, author and reviewer. Inspired by his insights and ideas, research in Drenckhahn's

Esther Asan

esther.asan@uni-wuerzburg.de

1 Institute of Anatomy and Cell Biology, University of Würzburg, Koellikerstr. 6, 97070 Würzburg, Germany group covered a wide range of topics including, for instance, cellular polarity, cytoskeleton characteristics and functions of various cell types in different tissues, epithelial and endothelial adhesion and barrier properties and their regulation, and resulted in numerous outstanding findings and publications. The basis for research remained the diligent structural analysis carried out on a state-of-the-art methodological level, and the interpretation of images guided by expert cell and tissue biological knowledge.

The idea to put together a Special Issue of Histochemistry and Cell Biology to acknowledge Detlev Drenckhahn's scientific and editorial work met with an overwhelmingly prompt and positive response, and I gladly accepted the role of a Guest Editor. The topics addressed in eight reviews cover a wide range, some closely related to Detlev Drenckhahn's research. Brand-Saberi and Zaehres present an enlightening account of how "anatomy, as a descriptive topic of research and instruction in medicine, has been influenced by recent discoveries in molecular cell and developmental biology", highlighting particularly the impact of stem cell research (Brand-Saberi and Zaehres 2016). The "brush cell", an epithelial cell for which a chemosensory function was first supported by findings of Drenckhahn's group (Höfer et al. 1996), is the topic of a review by Deckmann and Kummer, who assess morphological, biochemical and functional characteristics of chemosensory cells in the urethra (Deckmann and Kummer 2016). Schnittler portrays developments in research on contraction of endothelial cells, and on formation and control of endothelial intercellular junctions (Schnittler 2016). Rueckschloss, Kuerten and Ergün review studies on carcinoembryonic antigen-related cell adhesion molecule-1 (CEACAM1), focusing particularly on its function in vascular morphogenesis and endothelial barrier regulation (Rueckschloss et al. 2016). Neuhuber and Wörl summarize current knowledge on the possibly "still enigmatic" enteric co-innervation of vagally innervated motor endplates of esophageal striated muscle (Neuhuber and Wörl 2016). Three reviews focus on methodological advances and applications. 


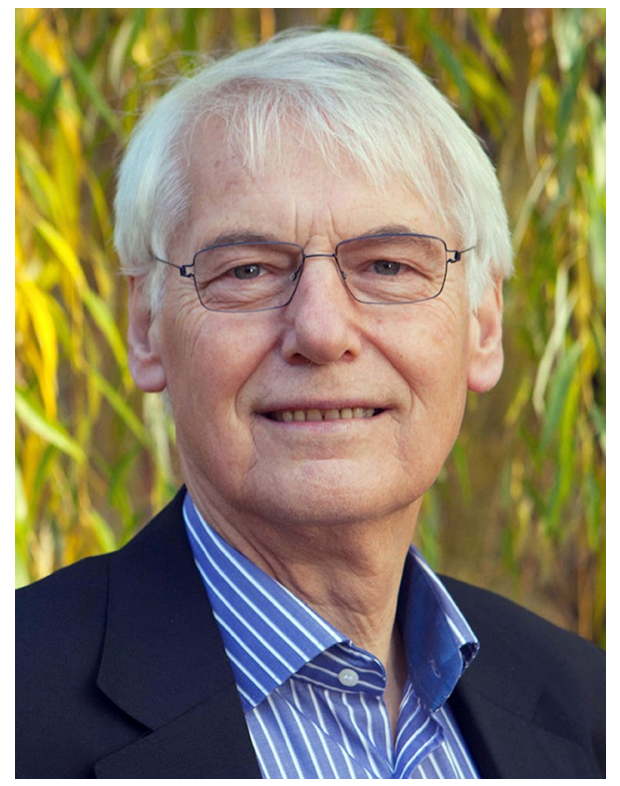

Fig. 1 Detlev Drenckhahn

Feuchtinger, Walch and Dobosz provide an impressive overview of state-of-the-art techniques in the rapidly evolving field of deep tissue imaging, involving light-sheet fluorescence microscopy, tissue clearing and staining methods, data quantification and 3D visualization, and present applications of these techniques in preclinical cancer research (Feuchtinger et al. 2016). Ochs, Mühlfeld and coworkers cast a look through the "retrospectroscope" on the history of studies of alveolar morphology, and provide an account of novel electron microscopic techniques and their application to investigations of the lung's functional design (Ochs et al. 2016). Buckinx and Timmermans review studies employing viral vectors to transduce different cell types in the intestine, focusing on a technology suited not only as a research tool but possibly also as therapeutic agent (Buckinx and Timmermans 2016). Five original articles present an equally broad range of subjects. Thus, Barth, Kasper and coworkers investigated the role of a specific purinergic receptor in the regulation of alveolar epithelial barrier functions (Barth et al. 2016). Rötzer, Egu and Waschke undertook the difficult task of documenting localization of desmosomes and desmosomal proteins in human Meibomian glands using light and electron microscopy (Rötzer et al. 2016). Ohlmann, Tamm and coworkers performed morphological and biochemical studies on embryonic and postnatal transgenic mice with ocular overexpression of transforming growth factor- $\beta$, documenting mesenchymal transdifferentiation of retinal pigment epithelial (RPE) cells, diminished RPE vascular endothelial growth factor production, consequent atrophy of the choriocapillaris, and photoreceptor apoptosis (Ohlmann et al. 2016). Weiss, Huppertz, Moser and coworkers studied first trimester human placenta, analyzing trophoblast plugs in spiral arteries and uterine glands to further our understanding of the role of these phenomena for placental blood flow (Weiss et al. 2016). Finally, Hartmann, Bergmann, Fietz and coworkers collected morphological, biochemical and functional evidence indicating that steroid synthesis via sulfatase pathway in Sertoli cells may contribute to paracrine and intracrine regulation in human testis (Hartmann et al. 2016).

It was a privilege for me to take part in editing this impressive Special Issue, to be able to contribute a short personal retrospective and to express my own appreciation of Detlev Drenckhahn and his contribution to Histochemistry and Cell Biology in this editorial.

\section{References}

Barth K, Bläsche R, Neißer A, Bramke S, Frank JA, Kasper M (2016) P2X7R-dependent regulation of glycogen synthase kinase $3 \beta$ and claudin-18 in alveolar epithelial type I cells of mice lung. Histochem Cell Biol. doi:10.1007/s00418-016-1499-3

Brand-Saberi B, Zaehres H (2016) The development of anatomy: from macroscopic body dissections to stem cell-derived organoids. Histochem Cell Biol. doi:10.1007/s00418-016-1497-5

Buckinx R, Timmermans JP (2016) Targeting the gastrointestinal tract with viral vectors: state of the art and possible applications in research and therapy. Histochem Cell Biol. doi:10.1007/s00418-016-1496-6

Deckmann K, Kummer W (2016) Chemosensory epithelial cells in the urethra: sentinels of the urinary tract. Histochem Cell Biol. doi:10.1007/s00418-016-1504-x

Feuchtinger A, Walch A, Dobosz M (2016) Deep tissue imaging: a review from a preclinical cancer research perspective. Histochem Cell Biol. doi:10.1007/s00418-016-1495-7

Hartmann K, Bennien J, Wapelhorst B, Bakhaus K, Schumacher V, Kliesch S, Weidner W, Bergmann M, Geyer J, Fietz D (2016) Current insights into the sulfatase pathway in human testis and cultured Sertoli cells. Histochem Cell Biol. doi:10.1007/s00418-016-1503-y

Höfer D, Püschel B, Drenckhahn D (1996) Taste receptor-like cells in the rat gut identified by expression of alpha-gustducin. Proc Natl Acad Sci USA 93:6631-6634

Neuhuber WL, Wörl J (2016) Enteric co-innervation of striated muscle in the esophagus: still enigmatic? Histochem Cell Biol. doi:10.1007/s00418-016-1500-1

Ochs M, Knudsen L, Hegermann J, Wrede C, Grothausmann R, Mühlfeld C (2016) Using electron microscopes to look into the lung. Histochem Cell Biol. doi:10.1007/s00418-016-1502-z

Ohlmann A, Scholz M, Koch M, Tamm ER (2016) Epithelial-mesenchymal transition of the retinal pigment epithelium causes choriocapillaris atrophy. Histochem Cell Biol. doi:10.1007/s00418-016-1461-4

Roth J (2016) Transition in HCB Editor-in-Chief. Histochem Cell Biol 145:1-3

Rötzer V, Egu D, Waschke J (2016) Meibomian gland cells display a differentiation-dependent composition of desmosomes. Histochem Cell Biol. doi:10.1007/s00418-016-1475-y

Rueckschloss U, Kuerten S, Ergün S (2016) The role of CEA-related cell adhesion molecule-1 (CEACAM1) in vascular homeostasis. Histochem Cell Biol. doi:10.1007/s00418-016-1505-9

Schnittler H (2016) Contraction of endothelial cells: 40 years of research, but the debate still lives. Histochem Cell Biol. doi:10.1007/s00418-016-1501-0

Weiss G, Sundl M, Glasner A, Huppertz B, Moser G (2016) The trophoblast plug during early pregnancy: a deeper insight. Histochem Cell Biol. doi:10.1007/s00418-016-1474-z 